\title{
Applied mineralogy of zirconium minerals: a case study of alkaline intrusion in SE-Brazil
}

\author{
Ana Olivia Barufi Franco-Magalhães ${ }^{1}\left[\right.$. Daniel Françoso de Godoy ${ }^{2}$
}

Received: 27 November 2020 / Accepted: 20 April 2021

Published online: 29 April 2021

(c) The Author(s) 2021 OPEN

\begin{abstract}
Brazil has important zirconium resources when compared with other countries. However, most of the zirconium production in Brazil occurs as coproduct of the mining and processing of heavy mineral sands for the titanium minerals. This paper reports mineral and technological characterization studies associated with an alkaline intrusion in SE-Brazil. The data were obtained in a complex local rock known as "caldasite," probably formed during hydrothermal alteration associated with post-magmatic events. The results obtained by multi-element analysis and X-ray diffraction analysis, petrography and scanning electronic microscopy indicated that zirconium concentration is about $66 \mathrm{wt} \%$, having zircon and baddeleyite as most relevant minerals; gibbsite and anatase are found in minor proportions. The mineral assemblage developed a complex rock texture and structure associated with hydrothermal fluids percolation indicated by remobilization of zirconium in primary rocks. Caldasite presented concentric growth banding texture, revealed by zircon nucleation and baddeleyite microcrystalline interlaying. Results obtained indicate that caldasite has a high potential as zirconium resource due to concentration and mineral associations.
\end{abstract}

\section{Article Highlights}

- This paper focused on the results of several techniques of mineralogical and technological characterization applied in an enriched-zirconium rock formed during hydrothermal alteration in alkaline intrusion in SE-Brazil.

- The results showed the rock is found in veins and has a mineral assemblage of zirconium, baddeleyite, gibbsite and anatase presented in a concentric growth banding texture.

- $\mathrm{ZrO}_{2}$ content is about $66 \%$ and preliminary results indicated the rock has a high potential for industry application.

Keywords Zirconium ore $\cdot$ Alkaline intrusion $\cdot$ Hydrothermal mineralization $\cdot$ Mineral characterization

\section{Introduction}

In the last decades, the search for new zirconium reserves has reached several countries that demand this resource for their industrial production, with great impact in the international market. Although Brazil is considered one of the global leaders of zircon production by heavy sands [1], there is a lack of information considering exploitation, new target areas and production data. On the other hand, the search for new sources

$\triangle$ Ana Olivia Barufi Franco-Magalhães, ana.magalhaes@unifal-mg.edu.br | ${ }^{1}$ Instituto de Ciência e Tecnologia, Universidade Federal de Alfenas UNIFAL-MG, Campus Poços de Caldas. Rodovia José Aurélio Vilela, n. 11999, Poços de Caldas, MG 37715-400, Brazil. ${ }^{2}$ Instituto de Geociências e Ciências Exatas, Universidade Estadual Paulista Unesp, Campus de Rio Claro. Avenida 24-A, n. 1515, Rio Claro, SP 13506-752, Brazil. 
of zirconium has been object of interest by several private companies, considering Brazilian reserves is apparently close to depletion.

Brazilian literature and government official data report zircon $\left(\mathrm{ZrSiO}_{4}\right)$, monazite $\left((\mathrm{Ce}, \mathrm{La}, \mathrm{Y}, \mathrm{Th}) \mathrm{PO}_{4}\right)$, ilmenite $\left(\mathrm{FeTiO}_{2}\right)$ and rutile $\left(\mathrm{TiO}_{2}\right)$ as fully extracted from heavy mineral sand deposits $[2,3]$, considering that they are different than other commodities in terms of exploration, development, mining and processing [4-6]. According to $[1,7]$, resources of zirconium in Brazil are about 2319 thousand metric tons (3.1\% of world resources) and the production is obtained from zircon mineral as a secondary source (placer deposit) along shorelines in the coast. No recent data/publication has included evidence for zirconium primary source related to intrusive alkaline rocks [1]. In this sense, this work presents data of mineralogical, petrographic and technological characterization of zirconium minerals with great potential as zirconium source, which is not associated with heavy mineral sand extraction and, therefore, mineralogy becomes important in order to define an eventual process mining.

The zirconium minerals studied in this research are associated with a rock having a local name of caldasite which were formed in the context of an alkaline intrusion of Mesozoic age [8], known as Poços de Caldas Alkaline Massif (PCAM) (Fig. 1). PCAM is a complex ring structure comprising a suite of alkaline volcanic and plutonic rocks (mainly phonolites and nepheline syenites) containing amounts of $U$, Th and rare-earth elements (REEs) typical for these rock types. The intrusion suffered regional post-magmatic deuteric and incipient hydrothermal alteration, resulting in widespread potassium metasomatism and zeolitization, together with minor argillation under oxidizing conditions (e.g., hematitization and hydrous ferric oxide-mineral formation) [9]. The massif was thus modified by hydrothermal fluid/rock interaction of local extent (primary mineralizing event), which led to pyritization, strong potassic metasomatism and to the formation of several important radioactive anomalies, such as $\mathrm{U}-\mathrm{Th}-\mathrm{Mo}, \mathrm{Zr}$ and REE mineralization occurred due to hydrothermal alteration conditioned by structural controls [8]. Geochemically, hydrothermal alteration leaches out $\mathrm{Ca}, \mathrm{Na}$ and $\mathrm{Mg}$ from the original rock, with concomitant introduction of $\mathrm{H}_{2} \mathrm{O}, \mathrm{CO}_{2}$ and $\mathrm{K}[8,10]$. Previous studies from $[11,12]$ related $\mathrm{Zr}$-enrichment to zirconium remobilization from primary $\mathrm{Zr}$-rich minerals.

Subsequent major evolutive stages of the intrusion included the emplacement of mafic-ultramafic dyke rocks (lamprophyres) and the onset of weathering, resulting in the formation of a surface laterite horizon and extensive saprolitization of the bedrock. Coeval with these low-temperature processes was the formation of descending redox fronts associated with the supergene remobilization and precipitation of uranium

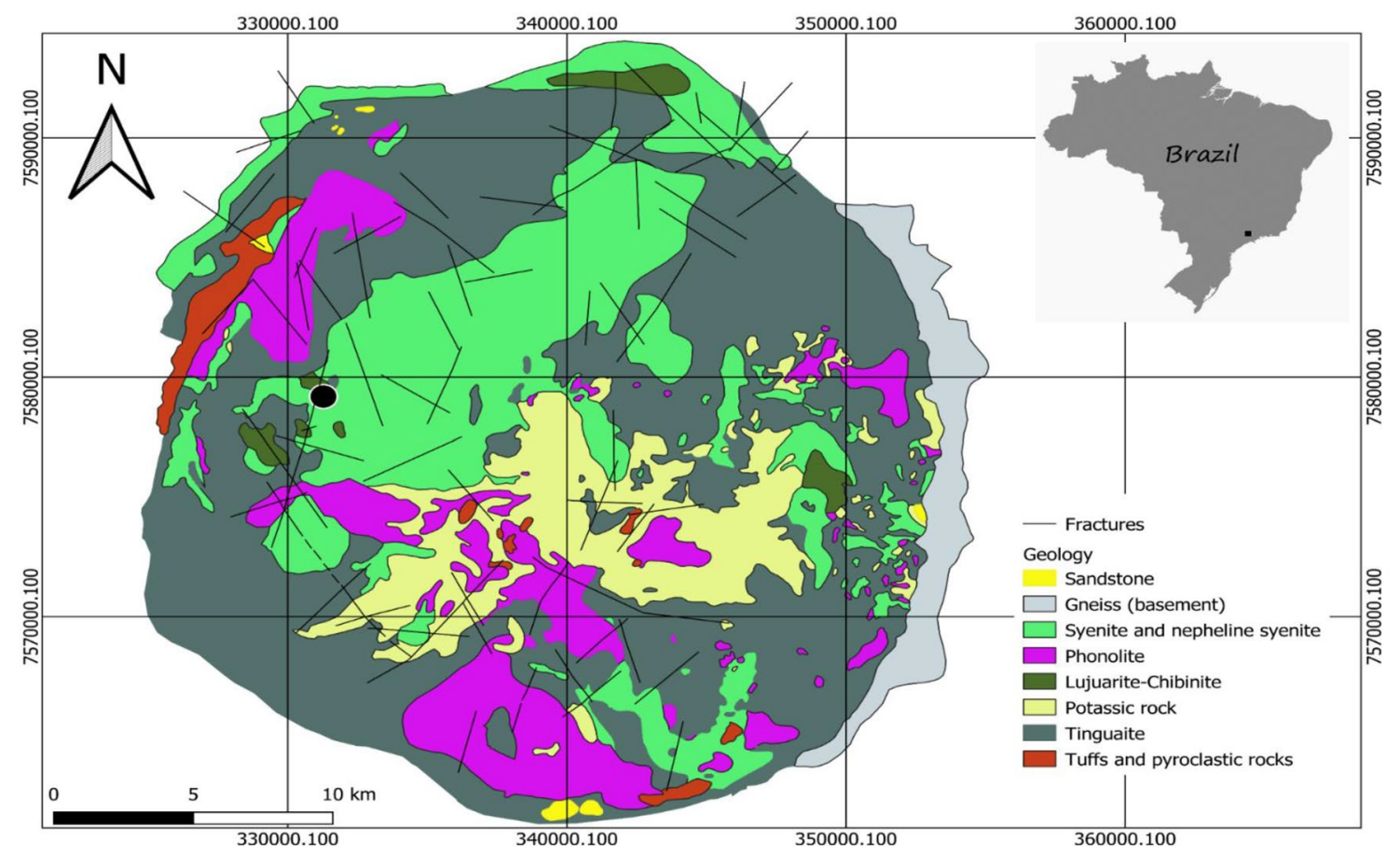

Fig. 1 Geological map of PCAM with the sample location (black dot). Geological base of CNEN (National Nuclear Energy Commission, Brazil) 
concentrations that have been exploited at the Osamu Utsumi mine area (secondary mineralizing event) $[8,9]$.

The ore-forming process resulting in caldasite formation is related to a $\mathrm{Zr}$-enriched rock found as subvertical veins in hydrothermally altered areas. According to [13], caldasite veins and alluvial deposits were explored by rudimentary methods until 1960's. However, not much about the mineralization and the geological context is known. The literature is not vast on the topic of zirconium mineralization in PCAM. Some studies have been focused in studying the chemical and thermal resistance of zircon from caldasite, such as $[14,15]$ and non-public information provided by federal government. Only few previous studies from 1960 's, for example $[8,11,13]$, were performed in the area, indicating that caldasite rock is an association of zircon $\left(\mathrm{ZrSiO}_{4}\right)$ and baddeleyite $\left(\mathrm{ZrO}_{2}\right)$, in different proportions from a few centimeters thick veins to meter-sizes pockets. Caldasite rock is widespread in PCAM, and the main occurrences are known as Serrote, Brígidas, Cercado, Taquari, Itororó and Vilela, which present approximately $70 \%$ of $\mathrm{ZrO}_{2}$ $[11,12]$.

This study presents chemical, mineralogical and petrographic information of caldasite rock and zirconium minerals in Serrote deposit, an important area of hydrothermal alteration in PCAM. The purpose of this paper is mineral characterization focused on the zirconium occurrences in PCAM and investigate detailed physical aspects and chemical concentration, considering that these resources show great potential for industry application. Also, this research provides unpublished data regarding zirconium mineralization in PCAM, in terms of the geological evolution and applied mineralogy. The results obtained by multiple techniques revealed that caldasite rock presents a great potential as a primary source of zirconium mineral in SE-Brazil. Although the literature about caldasite rock and Zr-mineralization in PCAM is scarce [8-12], and still under debate, these data represent a huge advance on this topic pointed by a resource's possible application in a complex geological context.

\section{Materials and methods}

\subsection{Samples and experimental procedures}

For this research, Serrote deposit (Fig. 1) was sampled in order to obtain data from technological and mineralogical characterization. The reasons for choosing this location were: (a) probably one of the deposits that was explored in the past, (b) easy access and location and (c) high Zr-content evidence.
It was collected approximately $37 \mathrm{~kg}$ of caldasite rock in Serrote deposit. The experimental procedure adopted for the mineralogical characterization was:

- Samples of the hard rock were separated for thin sections to petrographic and SEM analysis;

- The total amount of the sample was crushed in a jaw crusher under $3.35 \mathrm{~mm}$ fraction;

- The crushed product was homogenized, and head sample was separated;

- One fraction was milled in alumina ball mill under $0.180 \mathrm{~mm}$ fraction for whole rock chemical composition analysis and by size fraction distribution vs. chemical composition;

- Six samples of $300 \mathrm{~g}$ were separated for granulometric analysis and mineralogical characterization;

- Granulometric analysis by sieving was performed with screen apertures of $3.350,2.00,0.850,0.500$, $0.300,0.212,0.125,0.090$ and $0.075 \mathrm{~mm}$.

\subsection{Analytical methods}

Several analytical methods were applied in the Serrote sample deposit in order to understand chemical, mineralogical and petrographic features of caldasite rock and zirconium mineralization in PCAM. A complete sample characterization was obtained by combining different methods of analysis, such as described below.

Whole rock chemical composition analysis was determined by ICP-OES and ICP-MS analysis in SGS Geosol Laboratory (fusion method used lithium metaborate in a furnace). Loss on ignition (LOI) was done by sample calcination in a muffle furnace at $1000^{\circ} \mathrm{C}$. Routine quantitative analyses were carried out by X-ray fluorescence (XRF) in fused beads to determine the major oxides above $0.10 \mathrm{wt} \%$. For X-ray diffraction (XRD) analysis, the mineralogical composition was analyzed by $\mathrm{X}$-ray powder diffraction (XRD-6000, Shimadzu), with CuKa radiation scanning $2 \theta$ region from $14^{\circ}$ to $70^{\circ}$. The analysis was performed in a sample $0.075 \mathrm{~mm}$ size.

The modal mineralogy, elemental distribution in the bearing minerals, and mineral associations were obtained through scanning electron microscope analysis performed in JEOL-JSM 60/0LA equipment calibrated with certified reference standards. The analyses were performed considering the atomic number contrast [backscattered electron (BSE) images], the chemical composition of each mineral species (characteristic X-ray spectra by EDS) - XBSE mode and mineral textures. Petrographic analysis of thin sections with a polarized light microscope was performed in a Zeiss Axioscope A1 for textural identification. Mineral analyses to determine the 
zircon and baddeleyite morphology were done by stereoscopic microscope and SEM in grains under $0.212 \mathrm{~mm}$ and no immersion oil was used for this step.

\section{Results and discussion}

\subsection{Elemental chemical composition and chemical composition by size particle distribution}

The chemical composition of caldasite rock is presented in Table 1. Major oxides are $\mathrm{ZrO}_{2}(66 \mathrm{wt} \%), \mathrm{SiO}_{2}$ (23.7 wt\%), $\mathrm{Fe}_{2} \mathrm{O}_{3}$ (3.51 wt\%), $\mathrm{Al}_{2} \mathrm{O}_{3}(2.2 \mathrm{wt} \%)$ and $\mathrm{TiO}_{2}$ (1.01 wt\%). Critical contents such as thorium and uranium are about $2.08 \mathrm{wt} \%$ and $2.79 \mathrm{wt} \%$, which is expected as the area is known because the enrichment of radioactive elements in some hydrothermal alteration and weathering zones [8]. Results of chemical composition by particle size distribution indicated no variation on zirconium content in different size particle distributions (Fig. 2), and $\mathrm{ZrO}_{2}$ is roughly the same in all size fractions analyzed. Important points should be highlighted:

(a) $\mathrm{TiO}_{2}$ content, although very low, might be related to Ti-bearing primary minerals, such as anatase $\left(\mathrm{TiO}_{2}\right)$, pyrochlore $\left((\mathrm{Ca}, \mathrm{Na})_{2}(\mathrm{Nb}, \mathrm{Ti}, \mathrm{Ta})_{2} \mathrm{O}_{6}(\mathrm{OH}, \mathrm{F}, \mathrm{O})\right)$ and braunnerite $\left(\mathrm{UTi}_{2} \mathrm{O}_{6}\right)$, as previously described as primary Ti-minerals by $[4,9]$;

(b) According to [10], alkaline rock generally presents a ratio of $\left[\mathrm{Na}_{2} \mathrm{O}+\mathrm{K}_{2} \mathrm{O}: \mathrm{Al}_{2} \mathrm{O}_{3}: \mathrm{SiO}_{2}=1: 1: 6\right]$. Considering the primary rock of caldasite is an alkaline rock, this composition is not maintained in the caldasite rock because $\left[\mathrm{Na}_{2} \mathrm{O}+\mathrm{K}_{2} \mathrm{O}: \mathrm{Al}_{2} \mathrm{O}_{3}: \mathrm{SiO}_{2}=0: 1: 11\right]$ in such a case. This is an evidence that caldasite rock does not present alkaline affinity;

(c) Apparently, there is no relationship between $\mathrm{ZrO}_{2}$ content and particle size distribution (Fig. 2). Crushing and classification processes do not cause higher $\mathrm{ZrO}_{2}$ content in any fraction. The same behavior is observed with other selected oxides.

\subsection{Caldasite mineralogical composition and petrographic associations}

Powder XRD qualitative analysis indicated zircon, baddeleyite, gibbsite and anatase (Fig. 3) as constituent minerals. SEM and petrographic analysis evidenced a texture relationship of zircon and baddeleyite in different proportions displayed in a concentric growth banding (Figs. 4 and 5). Zircon is found as euhedral isolated or aggregates crystals, and baddeleyite is commonly observed as anhedral complex masses overlaying zircon crystals. The accessory
Table 1 Whole rock chemical composition

\begin{tabular}{|c|c|}
\hline ICP (ppm) & Serrote sample \\
\hline $\mathrm{Ce}$ & 956.6 \\
\hline Co & 6.7 \\
\hline Cs & 0.08 \\
\hline $\mathrm{Cu}$ & $<5$ \\
\hline Dy & 223.94 \\
\hline $\mathrm{Er}$ & 228.12 \\
\hline $\mathrm{Eu}$ & 33.8 \\
\hline Ga & 1.3 \\
\hline Gd & 110.34 \\
\hline $\mathrm{Hf}$ & $>500$ \\
\hline Ho & 59.01 \\
\hline La & 187.7 \\
\hline Lu & 48.07 \\
\hline Mo & 7 \\
\hline $\mathrm{Nb}$ & $>1000$ \\
\hline $\mathrm{Nd}$ & 229.3 \\
\hline $\mathrm{Ni}$ & $<5$ \\
\hline $\operatorname{Pr}$ & 56.11 \\
\hline $\mathrm{Rb}$ & 2.7 \\
\hline Sm & 75.5 \\
\hline Sn & 13.8 \\
\hline $\mathrm{Ta}$ & 11.12 \\
\hline $\mathrm{Tb}$ & 26.34 \\
\hline Th & 2793.3 \\
\hline $\mathrm{TI}$ & 0.9 \\
\hline Tm & 40.66 \\
\hline U & 2089.16 \\
\hline W & 43.5 \\
\hline Y & 1677.32 \\
\hline $\mathrm{Yb}$ & 312 \\
\hline \multicolumn{2}{|c|}{ XRF (Major elements; wt\%) } \\
\hline $\mathrm{SiO}_{2}$ & 23.7 \\
\hline $\mathrm{Al}_{2} \mathrm{O}_{3}$ & 2.2 \\
\hline $\mathrm{Fe}_{2} \mathrm{O}_{3}$ & 3.51 \\
\hline $\mathrm{CaO}$ & 0.09 \\
\hline $\mathrm{MgO}$ & 0.9 \\
\hline $\mathrm{TiO}_{2}$ & 1.01 \\
\hline $\mathrm{P}_{2} \mathrm{O}_{5}$ & 0.14 \\
\hline $\mathrm{Na}_{2} \mathrm{O}_{5}$ & 0.58 \\
\hline $\mathrm{K}_{2} \mathrm{O}$ & 0.06 \\
\hline $\mathrm{MnO}$ & 0.46 \\
\hline $\mathrm{U}_{3} \mathrm{O}_{8}$ & 0.22 \\
\hline $\mathrm{ZrO}_{2}$ & 66 \\
\hline LOI & 1.89 \\
\hline
\end{tabular}

minerals recognized in the sample are gibbsite $\left(\mathrm{Al}(\mathrm{OH})_{3}\right)$ and anatase $\left(\mathrm{TiO}_{2}\right)$. However, anatase was observed only in SEM analysis in very small proportions, and probably in an opened-space in vugs (Fig. 4e). Dark brown to black colors observed in the baddeleyite + gibbsite complex 


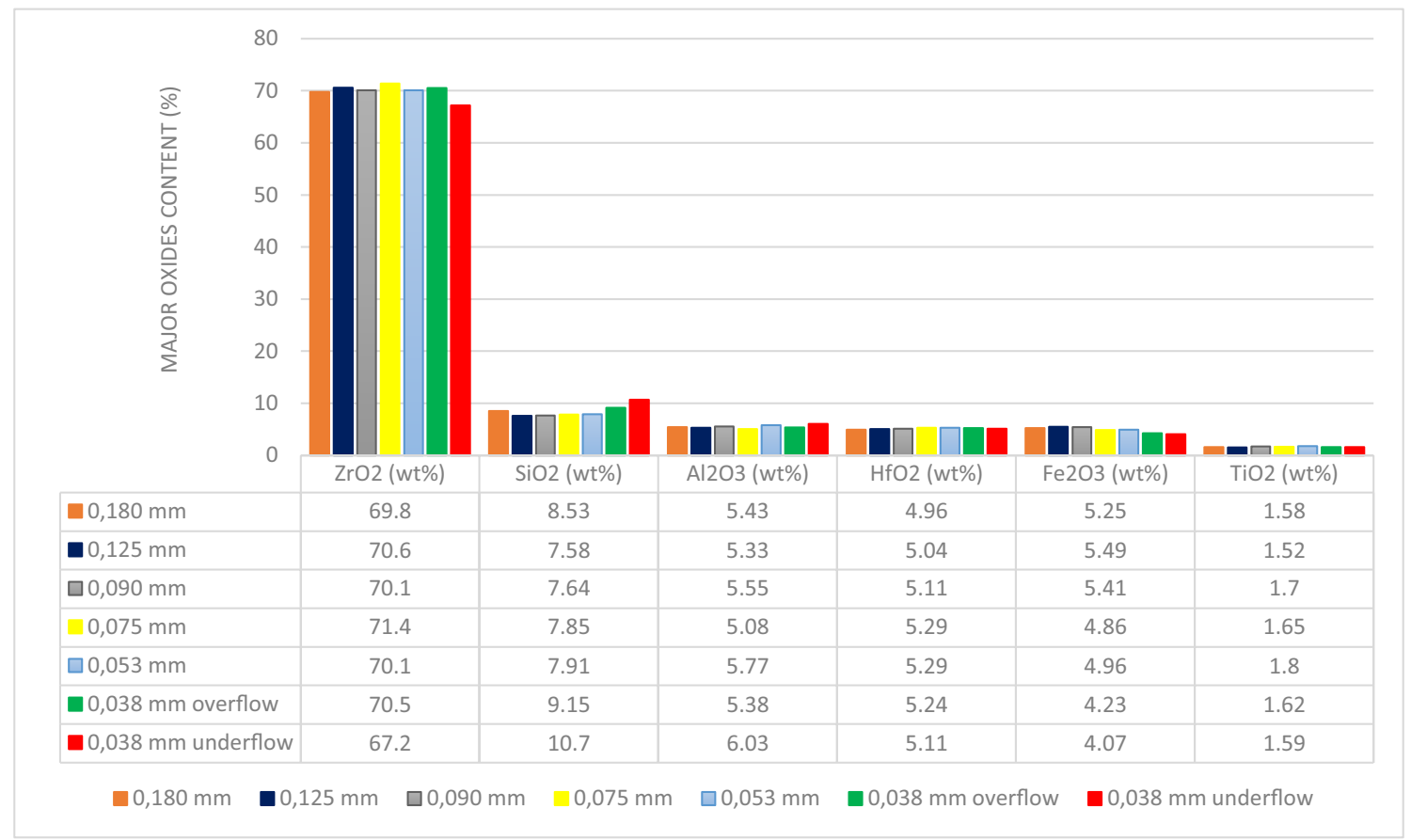

Fig. 2 Selected major elements (in oxides) by size fraction distribution of $0.180 \mathrm{~mm}, 0.125 \mathrm{~mm}, 0.090 \mathrm{~mm}, 0.075 \mathrm{~mm}, 0.053 \mathrm{~mm}, 0.038 \mathrm{~mm}$ overflow and $0.038 \mathrm{~mm}$ underflow. Note that there is not a huge difference on $\mathrm{ZrO}_{2}$ content considering size fraction analyzed

Fig. 3 XRD analysis from PCAM Zr-ore. XRD peaks intensity is highlighted in the figure by $\mathrm{Zr}$ : zircon $\left(\mathrm{ZrSiO}_{4}\right)$, Bd: baddeleyite $\left(\mathrm{ZrO}_{2}\right), \mathrm{Gb}$ : gibbsite $\left(\mathrm{Al}\left(\mathrm{OH}_{3}\right)\right)$ and At: anatase $\left(\mathrm{TiO}_{2}\right)$

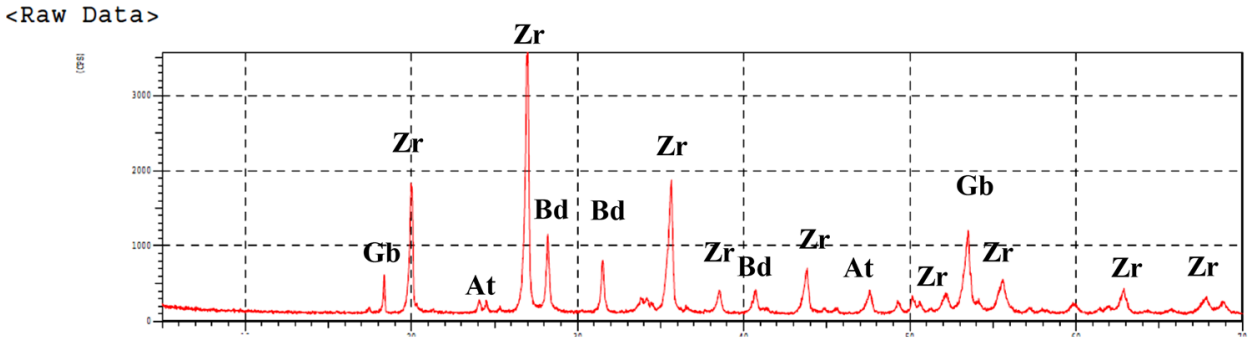

masses may indicate iron content in the crystal structure (Table 1; Fig. 5).

The concentric growth banding of zircon and baddeleyite filled in the open-spaced observed in caldasite rock can be associated with a primary texture of open-spaced deposition occurred in vugs or fractures developed by dissolution/leaching minerals or during faulting, as suggested by [16]. Minerals that exhibit texture of growthzoning by colloform or zoned monomineralic bands are associated with a change in the ore-forming fluids and the physical-chemical environment of mineralization with time, as observed in cooper-lead-zinc-silver assemblages in vein deposits in a variety of host rocks [17]. Colloform textures have often been observed as evidence for initial formation by colloidal deposition or into a supersaturated ore fluid, in Zn-ore types mineralization, such as described by [17], who also interpreted concentric growth banding as a result of colloidal reactions.

\subsubsection{Mineralogy and morphology of zircon and baddeleyite}

Determine mineral morphology is an important tool for understanding the geological history as a guide to the geological processes involved. Additionally, it works as an ore guide to exploration and target areas. During the last years, several publications have revealed this topic as an important applicability for applied studies [18-22].

To better understand how mineralogy and morphology of zircon and baddeleyite can influence on caldasite rock, especially on the rock-forming processes involved, grain samples were investigated under stereoscopic microscope and by SEM.

The results indicated that under stereoscopic microscope, zircon is light to dark brown, euhedral crystals with pyramidal morphology. A frequent covering of baddeleyite and gibbsite in zircon aggregates resulted 

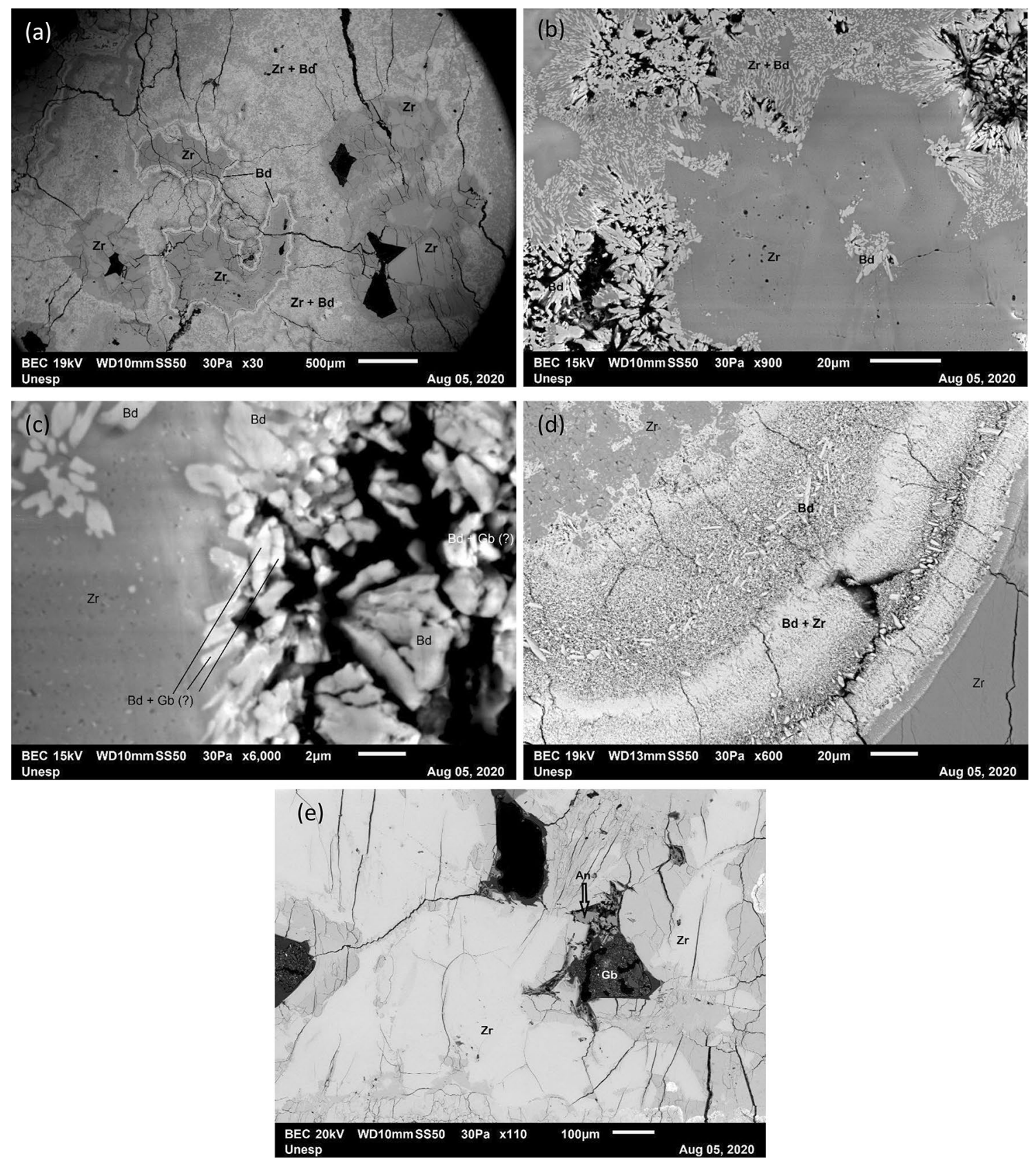

Fig. 4 SEM-BSE images. Aspects of zircon and baddeleyite crystals in a concentric growth banding $(\mathbf{a}, \mathbf{d})$; zircon nucleation and replacement of zircon to baddeleyite (b); baddeleyite and gibbsite

in yellow to pale brown colors in zircon grains (Fig. 6). Aggregates of zircon and baddeleyite, and less frequent gibbsite, can also be observed in SEM-BES images (Fig. 7). Prismatic zircon crystals with well-formed faces and variable in size are common but doubly terminated prismatic crystals are rare (Fig. 7).

The morphology of euhedral to subhedral prismatic zircons, typical for caldasite rock, was also identified micrometric aggregates (c); anatase and gibbsite (e). Zr: zircon, Bd: baddeleyite, Gb: gibbsite, An: anatase

in petrographic studies performed by transmitted light microscope (Fig. 5). In the analyzed samples, as observed in Figs. 4 and 5, zircons are unzoned and no metamict domains were detected. This is an important feature to understand that no $\mathrm{U}$-rich areas were revealed.

Corfu et al. (2003) suggested that several factors, including composition and temperature of 

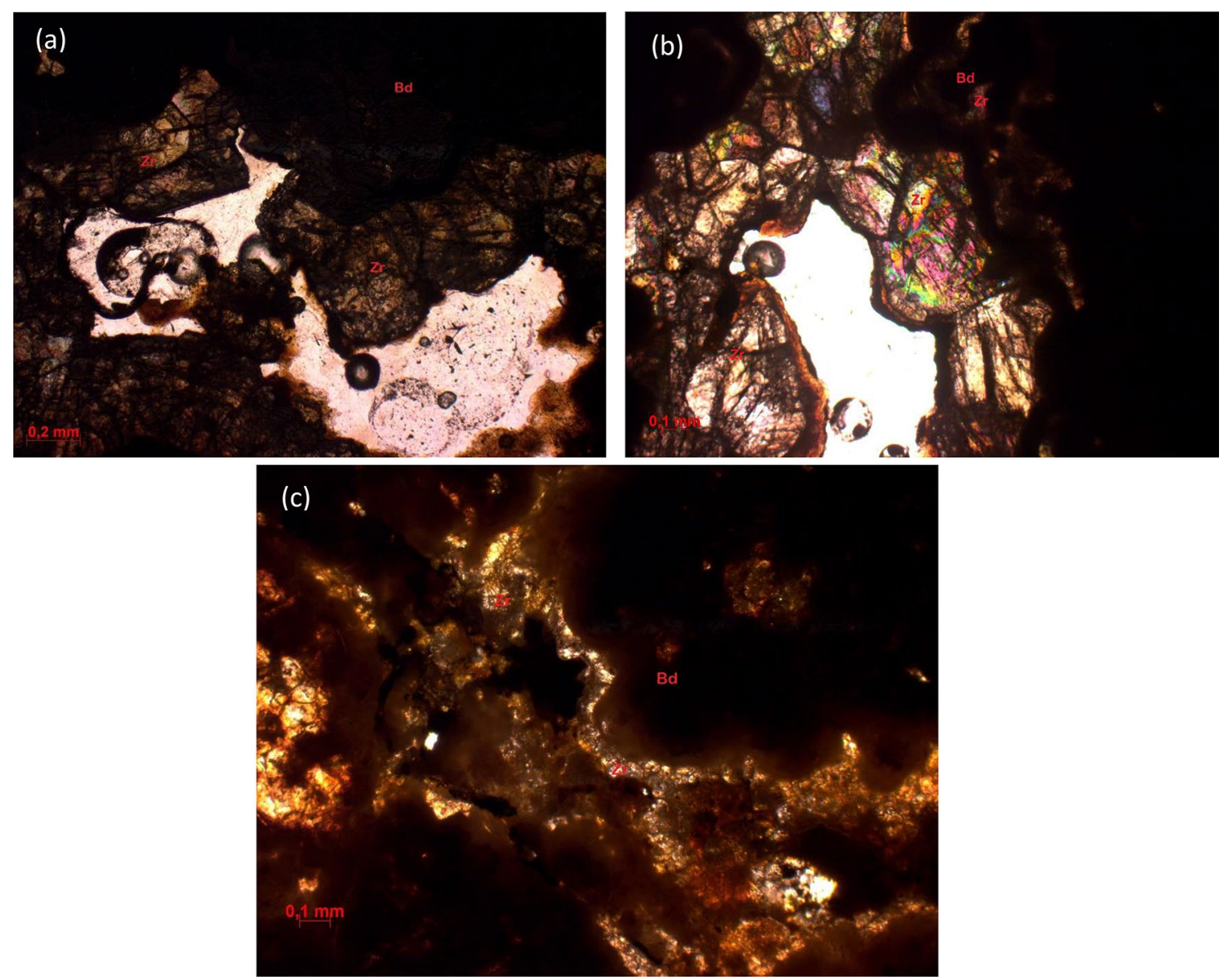

Fig. 5 Photomicrography and images analysis of a thin section of caldasite rock in polarized light. Aspects of zircon and baddeleyite crystals in vugs $(\mathbf{a}, \mathbf{b})$ and in concentric growth banding; zircon nucleation (c). Zr: zircon, Bd: baddeleyite

crystallization may affect the shape of crystals. The analyses performed indicated zircon-type aggregate, and no elongation ratio was possible to estimate. If it is not covered by baddeleyite, the prismatic morphology is easily observed. Euhedral to subhedral aggregates of zircons and the microtextural baddeleyite resulted in a typical habit/morphology for caldasite rock (Fig. 7).

\subsection{General considerations on the formation of caldasite rock}

Analyses performed by [9] indicated zirconium content on samples of nepheline syenites and phonolites in PCAM ranging from 858 to $1208 \mathrm{ppm}$. These relative high contents could be an evidence that hydrothermal alteration caused an enrichment of $\mathrm{Zr}$-content in caldasite according to the results obtained (66\%-Table 1$)$. Waber et al. [23] suggest that hydrothermal alteration leaches out mainly $\mathrm{Ca}$, $\mathrm{Na}$ and $\mathrm{Mg}$ from the original rock, with possible introduction of $\mathrm{U}-\mathrm{Zr}$-Mo-REE mineralization. This could explain that caldasite, although unique, is quite simple in the geochemical and mineralogical terms.

Regarding to gibbsite, although it has been detected in XRD and SEM analysis, a detailed description of its origin is still under debate. As caldasite is found in intimate association with hydrothermal alteration, it is possible that gibbsite is formed throughout veins in hydrothermally altered Al-rich rocks or, according to [8], gibbsite could even be formed as a product of weathering of fresh syenites and tinguaites resulting in laterite minerals. The fact is that in the analyzed sample, gibbsite is always found in association with baddeleyite, probably because of hydrothermalism and subsequent weathering.

The colloform banding observed in caldasite indicates a textural development with progressive growth probably from a single mass to form the colloform texture, from 

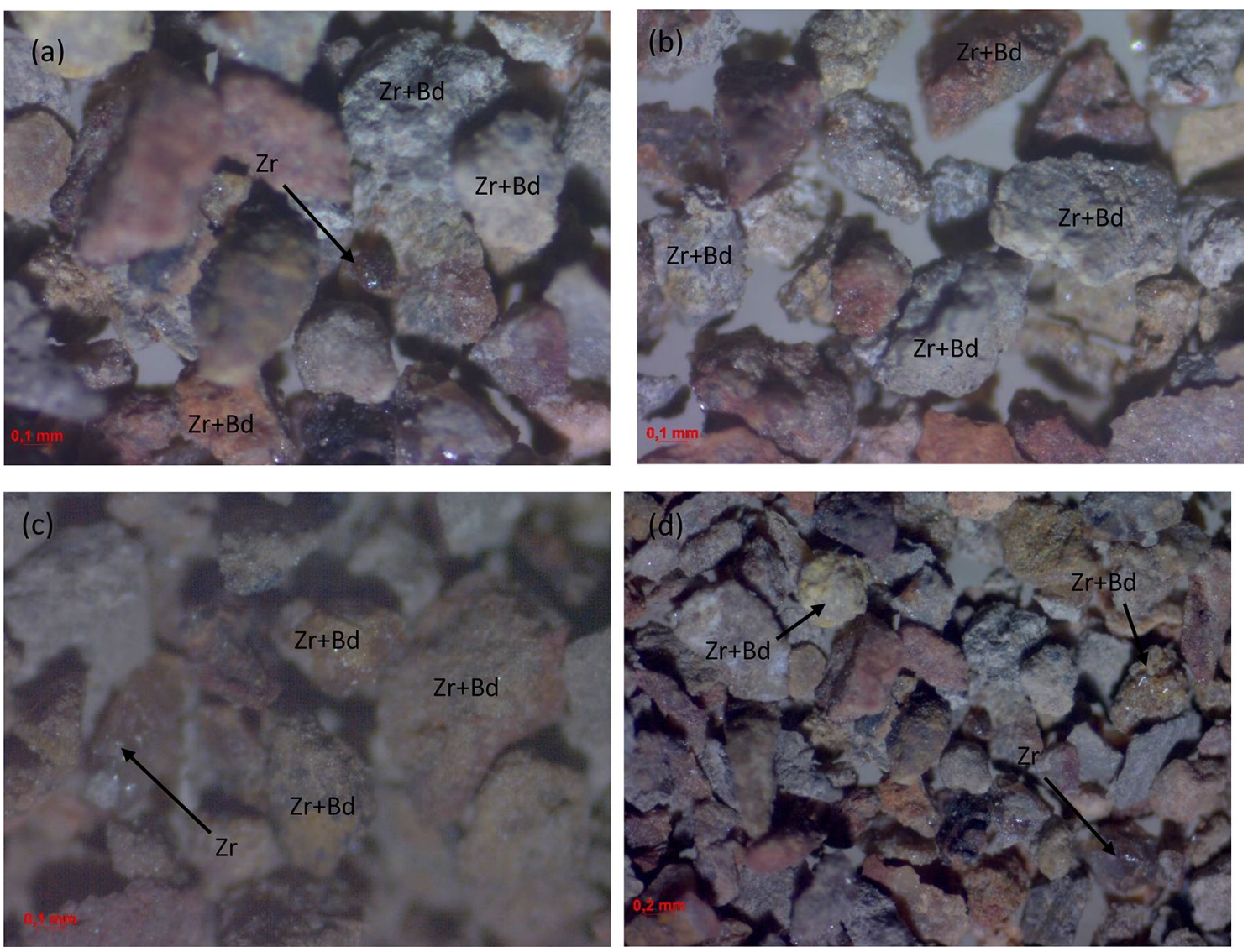

Fig. 6 Aggregates of zircon and baddeleyite in grains under $0.212 \mathrm{~mm}$ by stereoscopic microscope analysis. Note that is very frequent that zircons crystals are covered by yellow to pale brown

center-to-rim sequence of layers. Probably during the initial stages, a nucleation of zircon was formed, and then, fine-grained layers of baddeleyite bordering euhedral to subhedral zircon layers were deposited. During this process, replacement/recrystallization of zircon to baddeleyite also occurred. It was observed in SEM images a transitional gradient across the ore-forming zone (Fig. 4d). Apparently, the fractures observed in the petrographic analysis and SEM images have no influence on the ore-forming zone. It is important to highlight that the analyzes did not revealed metamict zones in zircon crystals. This is an important evidence that no high U-rich areas are observed in zircons.

The data obtained in this study indicate a colloform texture in zirconium minerals from hydrothermally altered rock. Roedder [17] affirmed that "colloform" ores have generally been considered to have been deposited as colloidal sulfide gels, and even transported as colloidal "sols." The author also concluded that colloform textures represent direct crystallization processes rather than colloidal aggregation. Thus, the term "colloform" should be utilized to describe a particular growth style and habit rather than a proposed growth mechanism.

baddeleyite (highlighted as $\mathrm{Zr}+\mathrm{Bd}$ ). In some cases, zircons are exposed and show no baddeleyite covering (marked as $\mathrm{Zr}$ )

\section{Conclusions}

Considering that zirconium source in Brazil is explored from heavy mineral deposits in coastline, this work presented results from a primary deposit related to an alkaline intrusion affected by hydrothermal episode. The results here obtained pointed out important information for mineral and technological characterization of zirconium minerals through the application of multiple techniques that indicated caldasite rock as an important potential to be applied for industry purposes due to zirconium concentration.

Previous paper published by [11] described zircon and baddeleyite in caldasite rock in PCAM (but with no information regarding chemical composition, mineralogical and petrographic characteristics and geological context). The results of this work evidenced that zircon, baddeleyite, gibbsite and anatase comprise the mineral assemblage of Serrote deposit. Petrographic and SEM analysis indicated a complex colloform texture that might be deeply investigated in terms of its genesis and mineralization. Although no Fe-bearing mineral was detected, further studies regarding $\mathrm{Fe}_{2} \mathrm{O}_{3}$ content are 

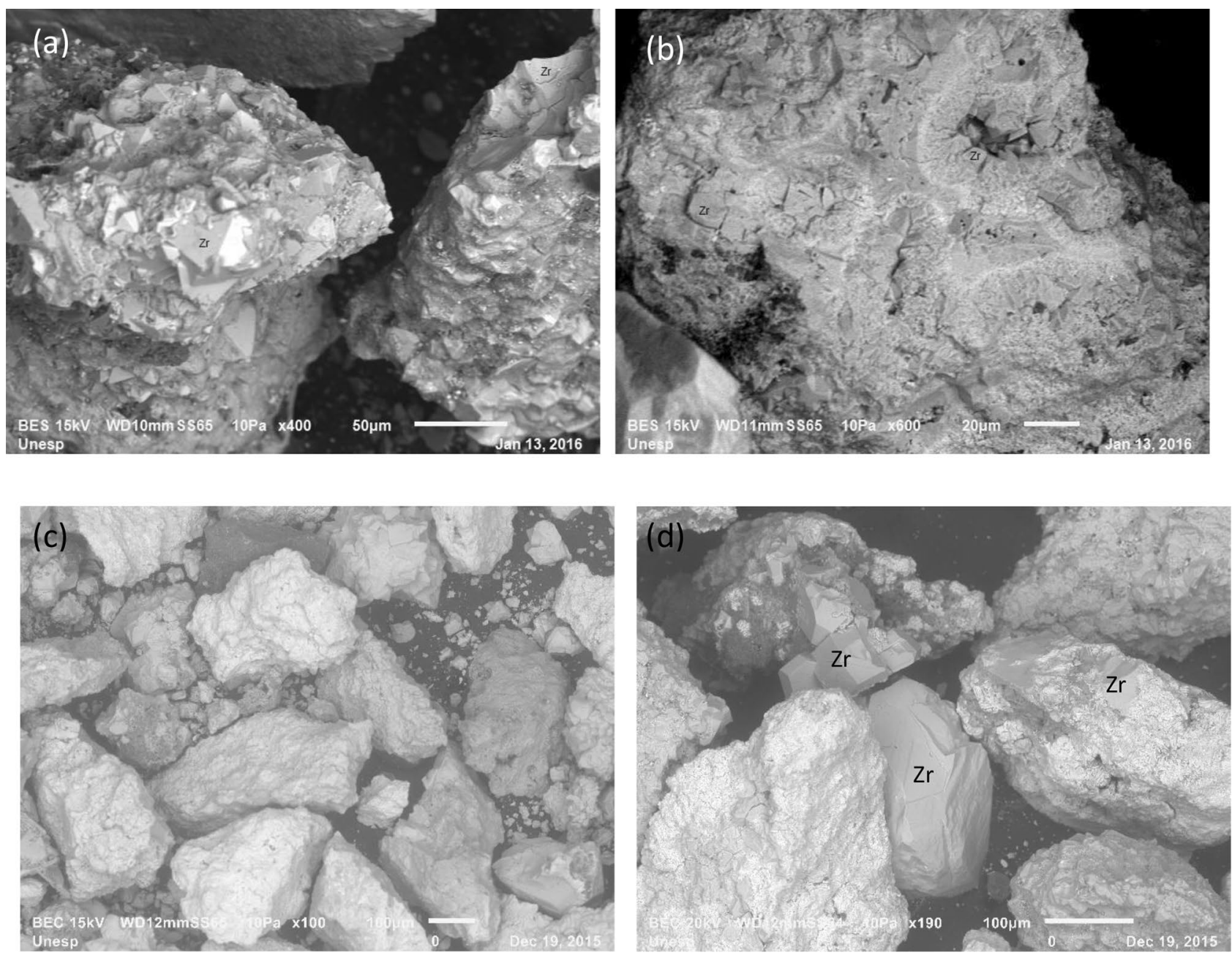

Fig. 7 Aggregates of zircon and baddeleyite in grains under $0.212 \mathrm{~mm}$ by SEM analysis. Note that zircon morphology is clear as pyramidal aggregates (marked as Zr). Vugs and colloidal texture were also observed in (b). Zircon presents euhedral to subhedral crystals

needed because it might be related to inclusions in zircon or either associated with gibbsite, because it brings considerable impact on beneficiation process.

Sampaio et al. [24] presented $\mathrm{ZrO}_{2}$ content about 62.68 to $65.29 \%$ to heavy mineral sands from NE-Brazilian coastline occurrences, with different concentration processes. The results obtained in this research from caldasite rock indicated $66 \%$ of $\mathrm{ZrO}_{2}$ content for Serrote deposit sample, which means it is slightly higher than placer deposits. If $\mathrm{Fe}_{2} \mathrm{O}_{3}$ is compared, data indicated $3.51 \%$ to Serrote sample and 2.62 a $0.15 \%$ to placer deposits. Preliminary, the results indicate that is not observed many differences in the raw material considering zircon from placer deposits (secondary source) or primary sources of alkaline intrusion.

In this way, it is reasonable to conclude that zirconium minerals from caldasite rock were formed during the hydrothermal alteration stage in PCAM. The percolation of hydrothermal fluids in fractures and/or intrusion bodies contact caused leaching of mainly $\mathrm{Ca}, \mathrm{Na}, \mathrm{Mg}$ and $\mathrm{Al}$ from the primary rock and concentrated zirconium minerals in a colloform texture with zircon nucleation and baddeleyite microcrystalline interlaying. Regarding to gibbsite, it is not clear how it was formed: either was during the hydrothermal process or weathering alteration.

The results indicated that due to the complexity of caldasite rock texture, and considering this is an important question to process mining, additional studies in other areas of the alkaline intrusion are desirable and should be integrated with a multidisciplinary approach. Moreover, several mineral processing tests such as attrition, electrostatic separation, magnetic separation, microwave heating and comminution must be applied aiming concentration process to obtain top quality final product.

Acknowledgments The author acknowledges the financial support of CNPq (National Council for Scientific and Technological Development, Brazil, Process 402837/2018-5). We thank the anonymous reviewers for very constructive comments and important suggestions. We also thank the Section Editor, Clifford Chuwah. 
Funding This research was supported by CNPq-Brazilian National Council for Scientific and Technological Development (process 402837/2018-5), entitled "Zirconium minerals in Poços de Caldas Alkaline Massif: a new approach based on mineralogical and technological characterization."

\section{Declarations}

Conflict of interest This paper presents results of research performed in a very particular and unique rock in SE-Brazil that researchers believed to be U-source. The efforts so far have been concentrated by other researchers in studying the alkaline rock ("host rock" of caldasite), the chronology of intrusion events and other mineral resources in the area (such as U, Th, REE). Only a few and outdated publications have been done to study "caldasite" rock. Based on these arguments, considering that previous research of $\mathrm{Zr}$-minerals has been performed in 1960 's, I deeply understand there is no conflicts of interest/competing interests.

Open Access This article is licensed under a Creative Commons Attribution 4.0 International License, which permits use, sharing, adaptation, distribution and reproduction in any medium or format, as long as you give appropriate credit to the original author(s) and the source, provide a link to the Creative Commons licence, and indicate if changes were made. The images or other third party material in this article are included in the article's Creative Commons licence, unless indicated otherwise in a credit line to the material. If material is not included in the article's Creative Commons licence and your intended use is not permitted by statutory regulation or exceeds the permitted use, you will need to obtain permission directly from the copyright holder. To view a copy of this licence, visit http://creativecommons. org/licenses/by/4.0/.

\section{References}

1. National Department of Mineral Production (DNPM). Sumário Mineral. c2010, c2011, c2012, c2013, c2014, c2015, c2016. http://www.anm.gov.br/dnpm/publicacoes/serie-estatistic as-e-economiamineral/sumario-mineral

2. Jones $G$ (2008) Mineral sands: an overview of the industry. lluka Company, Perth, p 26

3. Gonçalves CC, Braga PFA (2019) Heavy mineral sands in Brazil: deposits, characteristics, and extraction potential of selected areas. Minerals 9:176. https://doi.org/10.3390/min9030176

4. Schnellrath J, Monte MBM, Veras A, Júnior HR, Figueiredo CMV (2001) Minerais pesados INB. usinas de beneficiamento de minérios no Brasil. In: Sampaio JA, Luz AB, Lins FF (eds) Center for mineral technology: Rio de Janeiro, Brazil, p 189

5. Worobiec A, Stefaniak EA, Potgieter-Vermaak S, Sawlowicz Z, Spolnik Z, Grieken RV (2007) Characterization of concentrates of heavy minerals sands by micro-Raman spectrometry and CC-SEM/EDX with HCA. ApplGeochem 22:2078-2085

6. Gonçalves CC, Braga PFA (2016) In-depth characterization and preliminary beneficiation studies of heavy minerals from beach sands in Brazil. The Tenth International Heavy Minerals Conference. Sun City, 16-17 August 2016 Southern African Institute of Mining and Metallurgy.

7. Ministry of Mines and Energy (MME) (2019) Mineral sector bulletin. Secretariat of Geology, Mining and Mineral Transformation, Brazil, p 28

8. Ulbrich HH, Vlach SRF, Damaiffe D, Ulbrich MNC (2005) Structure and structure of the Poços de Caldas Alkaline Massif, SE
Brazil. In: Comin-Chiaramonti P, Gomes CB (eds) Mesozoic and Cenozoic Alkaline magmatism in the Brazilian Platform. São Paulo: Editora da Universidade de São Paulo: Fapesp, p 752.

9. Schorscher HD, Shea ME (1992) The regional geology of the Poços de Caldas alkaline complex: mineralogy and geochemistry of selected nephelinesyenites and phonolites. J GeochemExplor 45:25-51

10. Ulbrich HH, Ulbrich MNC (1992) O Maciço Alcalino de Poços de Caldas, MG-SP: Características petrográficas e estruturais. In: XXXVII Congresso Brasileiro de Geologia, São Paulo, Roteiro de Excursões, p 1-64

11. Tolbert GE (1958) Geochemistry of trace element concentrations in the Poços de Caldas Plateau, Brazil. Boletim da SociedadeBrasileira de Geologia 7(2):71-79

12. Garda GM (1990) Alteração Hidrotermal no contexto da evolução geológica do Maciço Alcalino de Poços de Caldas, MG-SP. Dissertação de Mestrado, São Paulo, Instituto de Geociências, Universidade de São Paulo. www.teses.usp.br

13. Tolbert J (1966) Theuraniferous zirconium deposits of the Poços de Caldas plateau, Brazil. US GeolSurv Bull 1185C:28

14. Brown AEP, Costa C (1972) Processing of a uraniferous zirconium ore. Publicação IEA Instituto de Energia Atômica n. 274.

15. Curtius AJ (1975) Radioactive disequilibria in Brazilian caldasite. InorganNuclChemLett 11:841-845

16. Craig JR, Vaughan DJ Ore microscopy and ore petrography, 2nd ed. Wiley, Hoboken, p 446

17. Roedder E (1968) Thenoncolloidal origin of "colloform" textures in sphalerite ores. Econ Geol 63:451-471

18. Dill H (2007) Grain morphology of heavy minerals from marine and continental placer deposits, with special reference to $\mathrm{Fe}-$ Ti oxides. Sediment Geol 198:1-27. https://doi.org/10.1016/j. sedgeo.2006.11.002

19. Gagnevin D, Daly JS, Kronz A (2010) Zircon texture and chemical composition as a guide to magmatic processes and mixing in a granitic environment and coeval volcanic system. Contrib Mineral Petrol 159:579-596. https://doi.org/10.1007/ s00410-009-0443-0

20. Dill H, Berthold W, Klosa D (2012) Morphology and mineral chemistry of monazite-zircon-bearing stream sediments of continental placer deposits (SE Germany): ore guide and provenance marker. J GeochemExplor 112:322-346. https://doi. org/10.1016/j.gexplo.2011.10.006

21. Yang WB, Niu HC, Shan Q, Sun WD, Zhang H, Li NB (2013) Yu XY (2014) Geochemistry of magmatic and hydrothermal zircon from the highly evolved Baerzhe alkaline granite: implications for Zr-REE-Nb mineralization. Mineral Deposita 49:451-470. https://doi.org/10.1007/s00126-013-0504-1

22. Bevins RE, Pirrie D, Ixer RA, O'Brien H, Pearson MK, Power MR, Shail RK (2020) Constraining the provenance of the Stonehenge 'Altar Stone': evidence from automated mineralogy and U-Pb zircon age dating. J ArchaeolSci 120:105188. https://doi. org/10.1016/j.jas.2020.105188

23. Waber N, Schorscher HD, Peter TJ (1992) Hydrothermal and supergene uranium mineralization at the Osamu UTsumi Mine, Poços de Caldas, Minas Gerais, Brazil. J GeochemExplor 45:53-112

24. Sampaio JA, Luz AB, Alcantara RM, Araújo LSL (2001) Minerais Pesados Millennium. Usinas de Beneficiamento de Minérios no Brasil. In: Sampaio JA, Luz AB, Lins FF (eds) Center for Mineral Technology: Rio de Janeiro, Brazil, p 233.

Publisher's Note Springer Nature remains neutral with regard to jurisdictional claims in published maps and institutional affiliations. 